\title{
Hospitalization of people 50 years old or older living with HIV/AIDS
}

\author{
Hospitalização de pessoas com 50 anos ou mais vivendo com HIVIAids \\ Hospitalización de personas de 50 o más años viviendo con VIH/SIDA
}

\section{Daiana Patrícia Marchetti Pio', Lilian Andreia Fleck Reinato", Letícia Pimenta Lopes", Juliano de Souza Caliari", Elucir Gir ${ }^{1, \text { II }}$}

\author{
' Universidade de São Paulo, Ribeirão Preto College of Nursing, Interunit Nursing Doctoral Program. \\ Ribeirão Preto, São Paulo, Brazil. \\ "Universidade de São Paulo, Ribeirão Preto College of Nursing, \\ Postgraduate Program in Fundamental Nursing. Ribeirão Preto, São Paulo, Brazil.
}

How to cite this article:

Pio DPM, Reinato LAF, Lopes LP, Souza JC, Gir E. Hospitalization of people 50 years old or older living with HIV/AIDS.

Rev Bras Enfer [Internet]. 2017;70(4):845-50. [Thematic Edition "Good Practices: Fundamentals of care

in Gerontological Nursing"] DOI: http://dx.doi.org/10.1590/0034-7167-2017-0113

Submission: 02-21-2017 Approval: 04-17-2017

\begin{abstract}
Objective: Identify the rate and predictive factors of the hospitalization of people living with HIV/AIDS (PLHA), aged 50 years or older. Method: A quantitative, cross-sectional study was conducted at two inpatient units specialized in infectious diseases in a teaching hospital. Data were gathered through individual interviews between August 2011 and February 2015. All ethical precepts were followed. Results: Of the 532 admitted patients, 95 were PLHA 50 years old or older; $30.5 \%$ were admitted 3 to 4 times after being diagnosed with HIV/AIDS. Conclusion: Rate of hospitalization was $17.8 \%$, and being 50 to 60 years old was a protective factor against hospitalization.
\end{abstract}

Descriptors: Hospitalization; HIV; HIV Long-term Survivors; HIV Infections; Opportunistic Infections.

\section{RESUMO}

Objetivo: Identificar a taxa e os fatores preditores para a hospitalização de pessoas vivendo com HIV/Aids (PVHA), com idade igual ou superior a 50 anos. Método: Estudo quantitativo, transversal, realizado em duas unidades de internação especializadas em cuidados às doenças infecciosas, de um hospital universitário. A coleta de dados foi realizada por meio de entrevista individual, no período de agosto de 2011 a fevereiro de 2015. Todos os preceitos éticos foram contemplados. Resultados: Das 532 internações, 95 eram de PVHA com idade igual ou superior a 50 anos; 56,8\% receberam o diagnóstico de HIV/Aids antes de terem completado 50 anos de idade; 30,5\% foram hospitalizadas de 3 a 4 vezes após o diagnóstico da infecção pelo HIV/Aids. Conclusão: A taxa de hospitalização foi de $17,8 \%$, e a faixa etária de 50 a 60 anos foi fator de proteção para a hospitalização.

Descritores: Hospitalização; HIV; Sobreviventes de Longo Prazo ao HIV; Infecções por HIV; Infecções Oportunistas.

\section{RESUMEN}

Objetivo: Identificar la tasa y los factores predictivos para hospitalización de personas viviendo con VIH/SIDA (PVHS), de edad igual o superior a 50 años. Método: Estudio cuantitativo, transversal, realizado en dos unidades de internación especializadas en cuidado de enfermedades infecciosas de un hospital universitario. Datos recolectados mediante entrevista individual, de agosto de 2011 a febrero de 2015. Fueron contemplados todos los preceptos éticos. Resultados: De las 532 internaciones, 95 correspondían a PVVS con edad igual o superior a 50 años; 56,8\% recibieron el diagnóstico de VIH/SIDA antes de Ilegar a sus 50 años; 30,5\% fueron hospitalizadas de 3 a 4 veces después del diagnóstico de infección por VIH/SIDA. Conclusión: La tasa de hospitalización fue del 17,8\%, y la faja etaria de 50 a 60 años constituyó factor de protección para la hospitalización.

Descriptores: Hospitalización; VIH; Sobrevivientes de VIH a Largo Plazo; Infecciones por VIH; Infecciones Oportunistas. 


\section{INTRODUCTION}

Controlling infection with the human immunodeficiency virus (HIV) is one of the greatest current global concerns, leading to intergovernment agreements involving joint measures to ensure that the global epidemic no longer poses a threat to public health ${ }^{(1)}$.

In Brazil, since June 2016, 842,710 cases of AIDS have been notified, which corresponds approximately to $0.4 \%$ of the Brazilian population infected by HIV. At the same time, this infection has been increasing progressively among the population aged 50 years or older, even though this age group is not the most affected by the disease ${ }^{(2)}$.

The advent of new technology has provided the population with greater life expectancy, resulting in the increase of individuals aged 50 years or older and who engage in more active social participation. This has culminated in the growth of individuals infected by HIV in this age group ${ }^{(3)}$.

Additionally, AIDS is now considered a chronic disease, given the evolution of available antiretroviral therapies, which enable greater survival rates and decrease morbimortality among people living with HIV/AIDS (PLHA) ${ }^{(3)}$.

However, even with the progress presented by antiretroviral therapy, aging with AIDS has become a greater challenge. There are strong indications that among this population, the HIV diagnosis is reached only after arduous investigation and exclusion of other pathologies. There is also the stigma associated with addressing sexuality with patients who are not considered young. All these elements result in delayed diagnosis, treatment and HIV prevention measures among this population ${ }^{(3)}$.

Furthermore, in addition to the natural conditions that arise from the aging process, such as increased cholesterol, osteoporosis, and increased blood pressure, antiretroviral drugs can cause strong side effects, such as diarrhea, nausea, vomiting, skin rashes, agitation, and insomnia. Even though these symptoms are considered acute, prolonged use of these drugs can also affect organs such as the liver, stomach, kidneys and even bones ${ }^{(4)}$.

It is also important to remember that, in addition to HIV treatment, PLHA need to treat other opportunistic diseases that may emerge due to their impaired immunological system.

The occurrence of these diseases usually leads to hospitalization. Thus, considering the entire health history of PLHA, they tend to have longer hospital stays and, consequently, are at greater risk for complications and death ${ }^{(4)}$.

Health professionals who work with this population must be properly trained in actions and strategies carried out more intensely at the most basic levels of health to avoid exposure to the nosocomial environment and diseases that the hospitalization process can present ${ }^{(5)}$.

This study is justified by the need to recognize the specificities of HIV infection among the population aged 50 years or older. This will enable the implementation of measures aimed at improving clinical management/handling and the feasibility of political and social care strategies for this population, in consonance with control of HIV infection control. Furthermore, by identifying the characteristics of this hospitalized population, this research can contribute to the assessment of the limitations of outpatient treatment in controlling HIV and its complications.

\section{OBJECTIVES}

To identify the rate and hospitalization among people living with HIV/AIDS aged 50 years old or older.

\section{METHOD}

\section{Ethical aspects}

The study protocol was approved by the Ethics Committee of the Ribeirão Preto College of Nursing at University of São Paulo (EERP/USP), in agreement with the recommendations set forth by the Brazilian National Health Council.

\section{Study design, location, population, sample and period}

This was a quantitative cross-sectional study conducted at two inpatient units specialized in infectious diseases of a public tertiary teaching hospital, in the state of São Paulo, Brazil. The hospital is part of the Unified Health System (SUS) and is recognized as a reference center by the Regional Health Department XIII (DRS XIII), covering 26 cities in the region of Ribeirão Preto, São Paulo, and caring for referred patients from other regions and even other states.

Participants were selected via convenience sampling between August 2011 and February 2015. Inclusion criteria were: being 50 years old or older, being aware of an HIV/ AIDS diagnosis, and presenting clinical conditions that enabled understanding instructions. Individuals with HIV/AIDS who were on any type of respiratory device hindering consent and/or interviews were excluded.

\section{Data collection}

Data were collected through individual interviews at the health care service, guided by a questionnaire that included the following variables: sociodemographic (gender, age, ethnicity, occupation); affective-sexual (sexual orientation, sexual partner and use of condoms in the six months prior to the study); epidemiological (category of exposure to HIV, time of HIV diagnosis); clinical (viral load and CD4 + T count); treatment (picking up ART prescriptions and ART prescription changes in the year prior to the study), and were correlated with the age group of HIV infection diagnosis (before 50 years old and/or 50 years old or older).

\section{Analysis of results and statistics}

The final data were compiled on Microsoft $^{\oplus}$ Office Excel $^{\circledR}$ 2010 for Windows 7 and were validated using double entry. The definite spreadsheet was transferred to IBM ${ }^{\circledR}$ SPSS software, version 20.0 .

Descriptive statistics, with simple frequency, was used for data analysis and sample characterization. The chi-squared test was employed to analyze the associations between variables and age group of HIV infection diagnosis. Crude and adjusted logistic regression models were used to identify predictive factors for hospitalization, calculating the odds ratio $(\mathrm{OR})$ as the estimator of association, with significance set at $5 \%$. 


\section{RESULTS}

During the study period, 532 individuals were admitted into the two participating units. Of these, $95(17.8 \%)$ were PLHA 50 years of age or older and were eligible to participate. Furthermore, $94.7 \%$ were from cities within the scope of the region covered by the DRSXIII and $32.7 \%$ had already been admitted more than three times due to HIV/AIDS-related complications.

In terms of sample characteristics, 58 (61.1\%) were male; 73 $(76.8 \%)$ were between 50 and 60 years old, mean age of 57.2 years $(S D \pm 6.1)$ and median equal to 55.2 years, with the maximum age of $76 ; 67(70.5 \%)$ were white and $45(47.4 \%)$ reported being employed. Regarding affective-sexual variables $76(80.0 \%)$ self-declared being heterosexual, $37(39.0 \%)$ informed having been with a sexual partner in six months prior to the study and $24(25.3 \%)$ declared having used condoms in the last 6 months. Exposure category was sexual for 68 (71.6\%) participants and 53 (55.8\%) had been diagnosed with HIV infection for at least five years. Regarding clinical characteristics, $41(43.2 \%)$ had a detectable viral load and $37(39.0 \%)$ a CD4 + T lymphocyte count less than or equal to 350 cells/ $/ \mathrm{mm}^{3}$. Regarding treatment, $63(66.3 \%)$ had picked up their antiretroviral prescription nine or more times in the year prior to the study and $68(71.6 \%)$ mentioned changing their therapy in this same period (Table 1).

Logistic regression analysis showed that the predictors that maintained statistical significance related to the age group of HIV infection diagnosis was the 50 to 60 age group and sexual category of exposure to HIV (Table 2).

Table 1 - Distribution of the association of variables of people living with HIV/AIDS who were hospitalized $(\mathrm{n}=95)$, according to age group of people diagnosed with HIV infection, state of São Paulo, Brazil, 2011-2015

\begin{tabular}{|c|c|c|c|c|c|c|c|}
\hline \multirow{3}{*}{ Variables } & \multicolumn{7}{|c|}{ People hospitalized with HIV infection diagnosis } \\
\hline & \multicolumn{2}{|c|}{ Younger than 50 years $(n=55)$} & \multicolumn{2}{|c|}{50 years old or older $(n=40)$} & \multicolumn{2}{|c|}{ Total } & \multirow[t]{2}{*}{$p$ value } \\
\hline & n & $\%$ & $\mathbf{n}$ & $\%$ & $\mathbf{n}$ & $\%$ & \\
\hline \multicolumn{8}{|l|}{ Sociodemographic } \\
\hline \multicolumn{8}{|l|}{ Gender } \\
\hline Male & 31 & 53.4 & 27 & 46.6 & 58 & 100 & \multirow{2}{*}{0.295} \\
\hline Female & 24 & 64.9 & 13 & 35.1 & 37 & 100 & \\
\hline \multicolumn{8}{|l|}{ Age group (years) } \\
\hline $50|--| 60$ & 48 & 65.8 & 25 & 34.2 & 73 & 100 & \multirow{2}{*}{0.007} \\
\hline$\geq 61$ & 7 & 31.8 & 15 & 68.2 & 22 & 100 & \\
\hline \multicolumn{8}{|l|}{ Ethnicity } \\
\hline White & 39 & 58.2 & 28 & 41.8 & 67 & 100 & \multirow{2}{*}{1.000} \\
\hline Black & 16 & 57.1 & 12 & 42.9 & 28 & 100 & \\
\hline \multicolumn{8}{|l|}{ Occupation } \\
\hline On medical leave/benefit & 6 & 66.7 & 3 & 33.3 & 9 & 100 & \multirow{4}{*}{0.436} \\
\hline Retired/receives pension & 15 & 53.6 & 13 & 46.4 & 28 & 100 & \\
\hline Unemployed & 10 & 76.9 & 3 & 23.1 & 13 & 100 & \\
\hline Working & 24 & 53.3 & 21 & 46.7 & 45 & 100 & \\
\hline \multicolumn{8}{|l|}{ Affective-sexual } \\
\hline \multicolumn{8}{|l|}{ Sexual orientation } \\
\hline Heterosexual & 45 & 52.6 & 31 & 47.4 & 76 & 100 & \multirow{2}{*}{0.796} \\
\hline Homo/Bisexual & 10 & 59.2 & 9 & 40.8 & 19 & 100 & \\
\hline \multicolumn{8}{|c|}{ Sexual partnership in the 6 months prior to the study } \\
\hline Yes & 16 & 43.2 & 21 & 56.8 & 37 & 100 & \multirow{2}{*}{0.033} \\
\hline No & 39 & 67.2 & 19 & 32.8 & 58 & 100 & \\
\hline \multicolumn{8}{|c|}{ Condom use in the 6 months prior to the study } \\
\hline Yes & 13 & 54.2 & 11 & 45.8 & 24 & 100 & \multirow{3}{*}{0.005} \\
\hline No & 3 & 21.4 & 11 & 78.6 & 14 & 100 & \\
\hline No relations & 39 & 68.4 & 18 & 31.6 & 57 & 100 & \\
\hline \multicolumn{8}{|l|}{ Epidemiological } \\
\hline \multicolumn{8}{|l|}{ Category of exposure to HIV } \\
\hline Sexual & 36 & 52.9 & 32 & 47.1 & 68 & 100 & \multirow{2}{*}{0.167} \\
\hline Nonsexual & 19 & 70.4 & 8 & 29.6 & 27 & 100 & \\
\hline \multicolumn{8}{|l|}{ Time of HIV diagnosis } \\
\hline$\leq 5$ years & 10 & 23.8 & 32 & 76.2 & 42 & 100 & \multirow{2}{*}{0.000} \\
\hline$>5$ years & 45 & 84.9 & 8 & 15.1 & 53 & 100 & \\
\hline
\end{tabular}


People hospitalized with HIV infection diagnosis

Variables

Younger than 50 years $(n=55) \quad 50$ years old or older $(n=40)$

n

$\%$

n

$\%$

Total $p$ value

\begin{tabular}{|c|c|c|c|c|c|c|c|}
\hline Clinical & & & & & & & \\
\hline \multicolumn{8}{|l|}{ Viral load count } \\
\hline$\leq 50$ copies $/ \mathrm{ml}$ (undetectable) & 22 & 59.5 & 15 & 40.5 & 37 & 100 & \multirow{3}{*}{0.300} \\
\hline$>50$ copies/ml (detectable) & 26 & 63.4 & 15 & 36.6 & 41 & 100 & \\
\hline No information & 7 & 41.2 & 10 & 58.8 & 17 & 100 & \\
\hline \multicolumn{8}{|l|}{ CD4 T count } \\
\hline$\leq 350$ cells $/ \mathrm{mm}^{3}$ & 23 & 60.0 & 14 & 40.0 & 37 & 100 & \multirow{3}{*}{0.321} \\
\hline$>350$ cells $/ \mathrm{mm}^{3}$ & 27 & 38.5 & 18 & 61.5 & 45 & 100 & \\
\hline No information & 5 & 57.9 & 8 & 42.1 & 13 & 100 & \\
\hline \multicolumn{8}{|l|}{ Treatment } \\
\hline \multicolumn{8}{|c|}{ Picking up ART prescription in the year prior to the study } \\
\hline Desirable ( $\geq 9$ pick ups) & 34 & 54.0 & 28 & 46.0 & 63 & 100 & \multirow{2}{*}{0.379} \\
\hline Undesirable (< 9 pick ups) & 21 & 65.5 & 11 & 34.4 & 32 & 100 & \\
\hline \multicolumn{8}{|c|}{ Number of ART alterations in the year prior to the study } \\
\hline Once & 8 & 61.5 & 5 & 38.5 & 13 & 100 & \multirow{3}{*}{0.142} \\
\hline Twice & 28 & 66.7 & 14 & 33.4 & 42 & 100 & \\
\hline 3 times & 11 & 42.3 & 15 & 57.7 & 26 & 100 & \\
\hline
\end{tabular}

Note: $C D 4+T=T$ lymphocyte cells; $A R T=$ antiretroviral therapy.

Table 2 - Odds ratio (OR) of statistically significant variables with the hospitalization of people with a diagnosis of HIV infection ( $\mathrm{n}=95)$, state of São Paulo, Brazil, 2011-2015

\begin{tabular}{|c|c|c|c|c|c|c|}
\hline Variables & Crude OR & $\begin{array}{c}* 95 \% \mathrm{Cl} \\
\text { Min - Max }\end{array}$ & $p$ value & Adjusted OR & $\begin{array}{c}* 95 \% \mathrm{Cl} \\
\text { Min - Max }\end{array}$ & $p$ value \\
\hline \multicolumn{7}{|l|}{ Age group (years) } \\
\hline $\begin{array}{l}50|--| 60 \\
\geq 61\end{array}$ & 0.072 & $\begin{array}{c}0.023-0.541 \\
\text { Reference }\end{array}$ & 0.001 & 0.221 & $\begin{array}{c}0.077-0.633 \\
\text { Reference }\end{array}$ & 0.005 \\
\hline \multicolumn{7}{|c|}{ Category of exposure to HIV } \\
\hline $\begin{array}{l}\text { Sexual } \\
\text { Non-sexual }\end{array}$ & 5.399 & $\begin{array}{c}1.155-25.241 \\
\text { Reference }\end{array}$ & 0.032 & 2.445 & $\begin{array}{c}0.883-6.773 \\
\text { Reference }\end{array}$ & 0.085 \\
\hline
\end{tabular}

Note: Min - Max = Minimum value - Maximum value

\section{DISCUSSION}

The characteristics of the studied population were similar to those of other PLHA in the same age group, with a prevalence of men ${ }^{(6-7)}$, diagnosed with HIV infection for over five years ${ }^{(6)}$, with sexual partnerships ${ }^{(7)}$, retired $^{(6)}$, with predominance of sexual exposure ${ }^{(6)}$ and CD4 count above 350 cells $/ \mathrm{mm}^{3(6)}$.

Among the analyzed variables, despite the statistically significant correlation of age group, time of diagnosis of HIV infection, sexual partnership and condom use in the six months prior to the study with the age group of HIV infection diagnosis of hospitalized PLHA, only the 50 to 60 year category of the age group variable was predictive of the participating sample, representing a protection factor against hospitalization. Thus, early diagnosis and in younger individuals served as a protection factor against the hospitalization of PLHA when compared with people who were diagnosed after the age of 50 .
Health is an essential factor in order to enjoy the opportunities provided by longevity, as decline in physical and cognitive capacity bring negative implications to individuals and society ${ }^{(8)}$.

A European study identified that late HIV/AIDS diagnosis was related to, among other factors, being 50 years old or older. The authors argued that the later the diagnosis of this infection, the lower the survival rate ${ }^{(9)}$.

An investigation on morbidities found that the older the individuals, the more likely they were to present several morbidities, with HIV/AIDS infection classified as the fourth most prevalent morbidity in the studied population ${ }^{(10)}$.

Another relevant study indicated that CD4 + T lymphocyte cell level above 350 cells $/ \mathrm{mm}^{3}$ and the use of ART significantly reduced risk of hospitalization ${ }^{(11)}$.

Research conducted in the state of Paraíba, Brazil, showed a gradual increase in the number of AIDS cases in the population aged 50 years or older, especially among people with brown skin, low education levels and heterosexual practices, 
emphasizing the need for health policies directed at this age group and the need to review health practices of multiprofessional teams, reconsidering the specificities of this population ${ }^{(12)}$.

One systematic review concluded that public policies should focus more on health promotion related to sexually transmitted diseases among older populations, as the behavior and epidemiological profile of this population has been constantly changing ${ }^{(13)}$.

\section{Study limitations}

The study sample was limited to 95 participants, as many patients did not meet the inclusion criteria. The main reason for exclusion were patients who were hospitalized more than once during the data collection period. Thus, the simultaneous application of this study in two locations enabled a larger sample of this population.

\section{Contributions to health}

Even though most of the participants were taking ART during hospitalization and were also classified as "desirable adherence", as they picked up 9 or more doses of antiretroviral drugs in the 12 months prior to their hospitalization, a high rate of patients presented detectable HIV viral loads and CD4 + T lymphocyte cell count below 350 cells $/ \mathrm{mm}^{3}$. These facts are seemingly contradictory and incite further investigation to identify possible therapeutic flaws and clinical management actions that can be implemented ${ }^{(14)}$.

\section{CONCLUSION}

The hospitalization rate of PLHA 50 years old or older was $17.8 \%$ in two health units specialized in infectious diseases at a large-scale teaching hospital in the state of São Paulo, Brazil. Among the variables related with hospitalization, the most significant was age group, showing that receiving a diagnosis between 50 and 60 years of age can act as a protective factor against hospitalization.

Recognizing the characteristics of this population implies formulating political and social strategies aimed at meeting the specificities and needs of this growing population. Such policies should aim for the hospitalization process of these individuals to be the last resource employed for reestablishing health conditions and, consider the implementation of measures that aim to control infection with HIV/AIDS.

\section{REFERENCES}

1. The Joint United Nations Programme on HIV/AIDS (UNAIDS). New report shows that urgent action is needed to end the aids epidemic by 2030 [Internet]. 2016 [cited 2017 Jan 17]. Available from: http://www.unaids.org/sites/default/ files/2016050 6_UNAIDS_SG_Report_on_HIV_en.pdf

2. Brasil. Ministério da Saúde. Boletim Epidemiológico - AIDS e DST. 01 a a $26^{\mathrm{a}}$ semanas epidemiológicas de janeiro a junho de 2016. V(1). Brasília: Ministério da Saúde; 2016.

3. Marin N, Luiza VL, Osório-de-Castro CGS, Machado-dos-Santos S, (orgs). Assistência farmacêutica para gerentes municipais. Rio de Janeiro: OPAS/OMS; 2003.

4. Saldanha AAW, Araújo LF, Felix SMF Aids na velhice: os grupos de convivência de idosos como espaços de possibilidades. In DVS Falcão, CMSB. Dias (Eds.). Maturidade e velhice: pesquisas e intervenções psicológicas. São Paulo: Casa do Psicólogo; 2006. p 225-45.

5. Montessori V, Press N, Harris M, Akagi L, Montaner JSG. Adverse effects of antiretroviral therapy for HIV infection. Canadian Medical Associations. 2004; 170(2):229-38.

6. Okuno MFP, Gomes AC, Meazzini L, Júnior GS, Junior DB, Belasco AGS. [Quality of life in elderly patients living with HIV/AIDS]. Cad Saúde Pública [Internet]. 2014 [cited 2016 Jul 16];30(7):1551-9. Available from: http://www.scielo.br/pdf/csp/v30n7/0102-311X-csp-30-7-1551.pdf Portuguese.

7. Lopes PSD, Silva MMG, Torres IC, Stadñik CMB. Qualidade de vida dos pacientes HIV positivo com mais de 50 anos. Rev Assoc Médica RGSul. 2011; 55(4):356-360.

8. Linhares $C D$, Tocantins FR, Lemos A. Ações de enfermagem na atenção primária e qualidade de vida do idoso: revisão integrativa. Rev Pesqui: Cuid Fundam [Internet]. 2014 [cited 2016 Jul 16];6(4):1630-41. Available from: http://pesquisa.bvsalud. org/saudepublica/resource/pt/bde-25842

9. Brasil. Ministério da Saúde. Protocolo clínico e diretrizes terapêuticas para adultos vivendo com HIV/Aids. Brasília, 2013. 216p

10. World Health Organization. World Report on Ageing and Health. WHO Press, Geneva. 2015.

11. Mocroft A, Lundgren J, Antinori A, Monforte Ad, Brännström J, Bonnet F, et al. Late presentation for HIV care across Europe: update from the Collaboration of Observational HIV Epidemiological Research Europe (COHERE) study, 2010 to 2013. Euro Surveill [Internet]. 2015 [cited 2016 Jul 16];20(47):7-18. Available from: https://www.ncbi.nlm.nih.gov/pubmed/26624933

12. Lenzi J, Avaldi VM, Rucci P, Pieri G, Fantini MP. Burden of multimorbidity in relation to age, gender and immigrant status: a cross-sectional study based on administrative data. BMJ Open [Internet]. 2016 [cited 2017 Jan 17];6(12). Available from: http:// bmjopen.bmj.com/content/6/12/e012812.full

13. Crum-Cianflone NF, Grandits G, Echols S, Ganesan A, Landrum M, Weintrob A, et al. Trends and causes of hospitalizations among HIV-infected persons during the late HAART era: what is the impact of CD4 cell counts and HAART use? J Acquir Immune 
Defic Syndr [Internet]. 2010 [cited 2016 Jul 16];54(3):248-57. Available from: https://www.ncbi.nlm.nih.gov/pubmed/20658748

14. Dornelas-Neto J, Nakamura AS, Cortez LER, Yamaguchi UM. Doenças sexualmente transmissíveis em idosos: uma revisão sistemática. Ciênc Saúde Colet [Internet]. 2015 [cited 2016 Jul 16];20(12):3853-64. Available from: http://www.scielo.br/pdf/csc/ v20n12/1413-8123-csc-20-12-3853.pdf 